\title{
Phytochemical and mineral content of pulp drink and analogue yoghurt from pretreated balanaites aeqyptiaca fruit pulp
}

\begin{abstract}
Production, phytochemical characteristics and mineral contents of pulp rink and analogue yoghurt from pretreated balanaites aeqyptiaca fruit pulp were investigated. Production of rink a yogurth analogy ewer mae from balanite fruit via boiling sifting, water elution to make pulp rink. A yoghurt stock was ration with pulp rink sample at 50:50 dilution and allow to ferment over night to make analogue yogurth fron balanaites pulp. Results revealed that taninin, saponin, flavonoids and alkaloid were present in pup rink qualitatively. Tannin and saponin were not found in yogurth samples except flavonoids and a alkaloids. The mineral content were favorable in the drink, for $\mathrm{Zn}$ at $(0.0306 \mathrm{mg} / \mathrm{L}), \mathrm{Cu}$ at $(0.6328 \mathrm{mg} / \mathrm{L})$, $\mathrm{Fe}$ at $(2.796 \mathrm{mg} / \mathrm{L}), \mathrm{Mg}$ at $(18.5767 \mathrm{mg} / \mathrm{L})$ and $\mathrm{Ca}$ at $(6.6783 \mathrm{mg} / \mathrm{L})$ compared with the control; ( Zn, 0.0250mg/L) (Cu,0.0103mg/L)mg/L, (Fe.1.3001mg/L), (Mg 17.1005mg/L), $(\mathrm{Ca}, 46.3778 \mathrm{mg} / \mathrm{L})$. Only $\mathrm{Zn}$ and $\mathrm{Cu}$ were found abundant in balanites analogue yoghurt at 50:50 blend ratios compare with the control. Production of balanites juice and analogue yoghurt are possible and could fight age related nutrition, hidden hunger and alternative to imported black currant drink and expensive powdered milk base which are not affordable by our rural society.
\end{abstract}

Keywords: production, balanite drink, analogue yoghurt, phytochemical, minerals, nutrition
Volume 6 Issue 6 - 2017

\author{
Ogori AF,' Orede VO,' Wakawa LD, ${ }^{2}$ Makinde \\ OJ $\}^{3}$ \\ 'Department of Home Science, Nigeria \\ ${ }^{2}$ Departments of Forestry and Wildlife Management, Nigeria \\ ${ }^{3}$ Department of Animal Science, Nigeria
}

Correspondence: Ogori AF, Department of Home Science, Faculty of Agriculture, Federal university, PMB I005, Yobe state, Gashua, Nigeria, Email ogorifaraday@gmail.com

Received: July 02, 2017 | Published: August 04, 2017

\section{Introduction}

There have been significant use of plants, for food and as animal protein substitutes, this is arousing interest among consumers, dieticians and nutritionists. Plants are now being used in the preparation of food of high energy value by dietetics: yoghurt, flour for babies, jams, marmalades. It has been reported that dates products have been developed including Ketchup, ${ }^{1}$ biscuits, ${ }^{2}$ ice, ${ }^{3}$ Tamarheep (a mixture of flour of dates and milk), ${ }^{4}$ flour of dates and yogurt with extract of dates. ${ }^{5}$ Fresh fermented dairy products such as yoghurt are widely consumed foods in many countries. ${ }^{6}$ Yogurt is one of the most dairy products sold on the market because of the diversification of its constitution, such as fat yoghurt, probiotic yoghurt, yoghurt mousse, ice cream yoghurt, liquid yoghurt for drinking ${ }^{7}$ yoghurts are healthy food because of its beneficial live bacteria. However, in competition with pathogenic bacteria in both food and the environment. ${ }^{8}$ The extract of balanites such as pulp, leaves, juice had been reported to be rich in micro and macro nutrients especially proteins and vitamins. ${ }^{1}$ Dates are rich in fiber and pectin minerals such as $(\mathrm{Ca}, \mathrm{P}, \mathrm{K}, \mathrm{Fe})$ and other biological active substances like Group B vitamins, essential amino acids and polyphenols. ${ }^{9}$ The purpose of this research is to Make yoghurt analogue from balanites pulps drink, as a functional food base material that may meets consumers' expectations in the modern day of infection, diseases and age related issues. These potentials, balanites polyphenols contents has. ${ }^{1,6}$ This research work seeks to establish the best analogue yogurt and juice products from banalities pulp produce at various pretreatments for children and adult that depends on milk, milk intolerance people as well as ovo-lacto vegetarians. The bioactive, minerals and vitamins contents may help against hidden hunger.

\section{Materials and methods}

Balanites pulp: The fruit from balanites were picked from the floor from and around the university campus, Sorting was done on pulp made by boiling. The pulp was sieved and diluted with an equal amount of water to make a balanites pulp drink

\section{Milk used for the manufacture of yoghurt}

The milk used was full cream dehydrated powdered peak brand milk.

Starter organism: Raw fresh cow milk was used for dilution culture preparation or as operation culture. Milk contains lactic acid fermenters with dominant species containing Streptococcus thermophilus and Lactobacillus bulgaricus as natural sourced starter.

The balanites drink used for manufacture of yoghurt: The drink was obtained after heating fruit to pulping at $80^{\circ} \mathrm{C}$ for one hour, followed by hot sifting there after diluting with equal amount of water to make balanites drink. This drink was also used as base for the analogue yoghurt preparation (Figure 1) (Figure 2).

Yoghurt making: The preparation of the balanites yoghurt analogue was done at the science laboratory of the Federal University Gashua. Standard yoghurt with a modification concerning the substitution of balanites was prepared. This was simmered with pulp drink on combination. The culture sample was allowed to stay for 24hours for maturation of the yoghurt analogue. This is shown in Figure 1. 


\section{Phytochemical screening of fresh yoghurt}

Analogue yoghurt, currant drink and pulp drink of Balanites aegyptiaca fruits were carried out according to the methods of (Figure 1) (Figure 2). ${ }^{10,11}$

\section{Alkaloids}

$0.5 \mathrm{~g}$ extracts from pulp drink and pulp yoghurt were diluted with $10 \mathrm{~mL}$ of acid alcohol, boiled and filtered. To $5 \mathrm{ml}$ of the filtrate was added $2 \mathrm{~mL}$ of dilute ammonia, $5 \mathrm{~mL}$ of chloroform was added and shaken gently to extract the alkaloid base. The chloroform layer was extracted with $10 \mathrm{~mL}$ of acetic acid. This was divided into two parts each of the samples. Mayer's reagent was added to one portion of the sample and Draggendoff's reagent was added to other portion of the sample. The formation of cream (with Mayer's reagent) or reddish brown precipitate (with Draggendoff's reagent) indicates the presence of alkaloid.

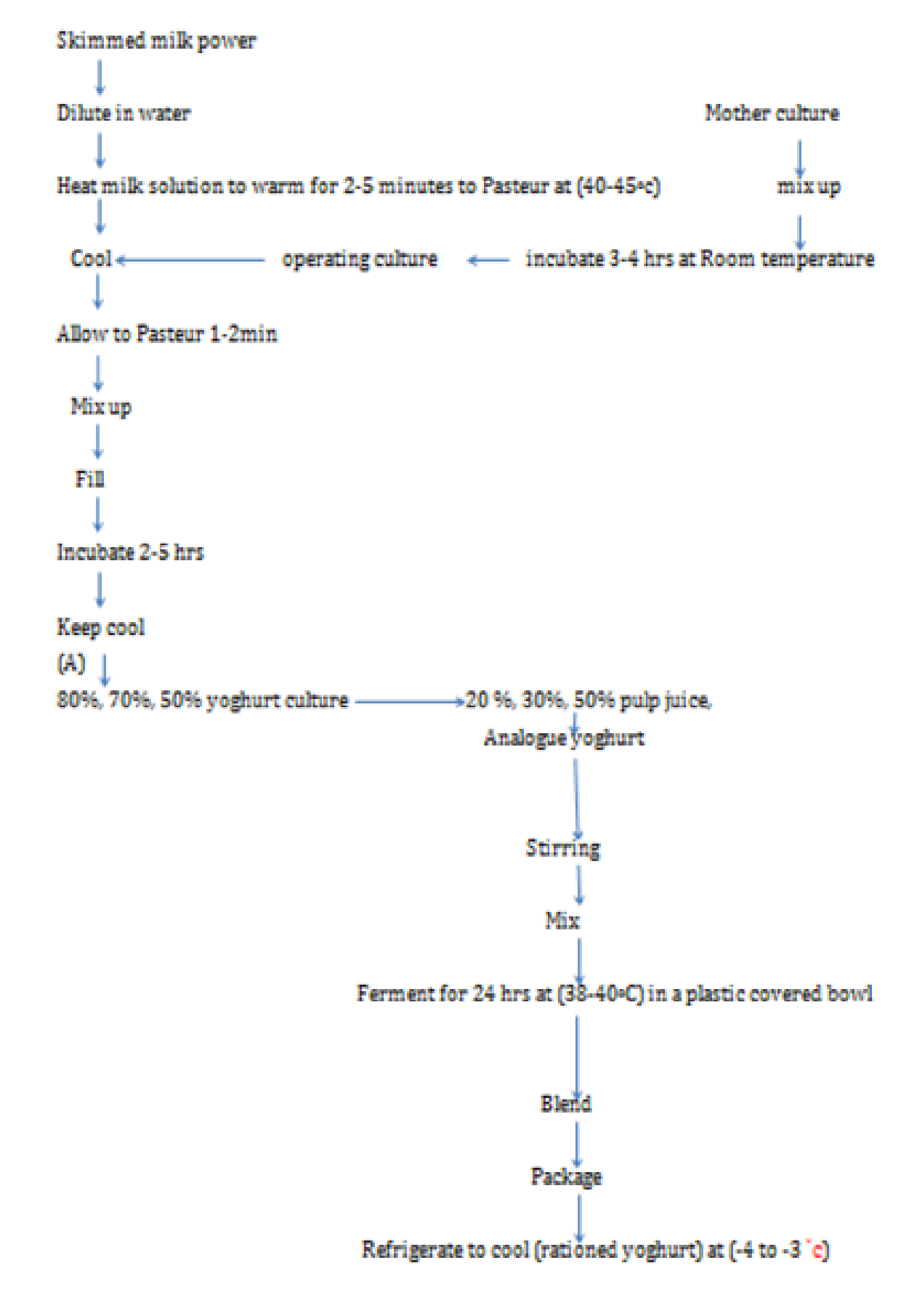

Figure I Making of Analogue ration Yoghurt. 


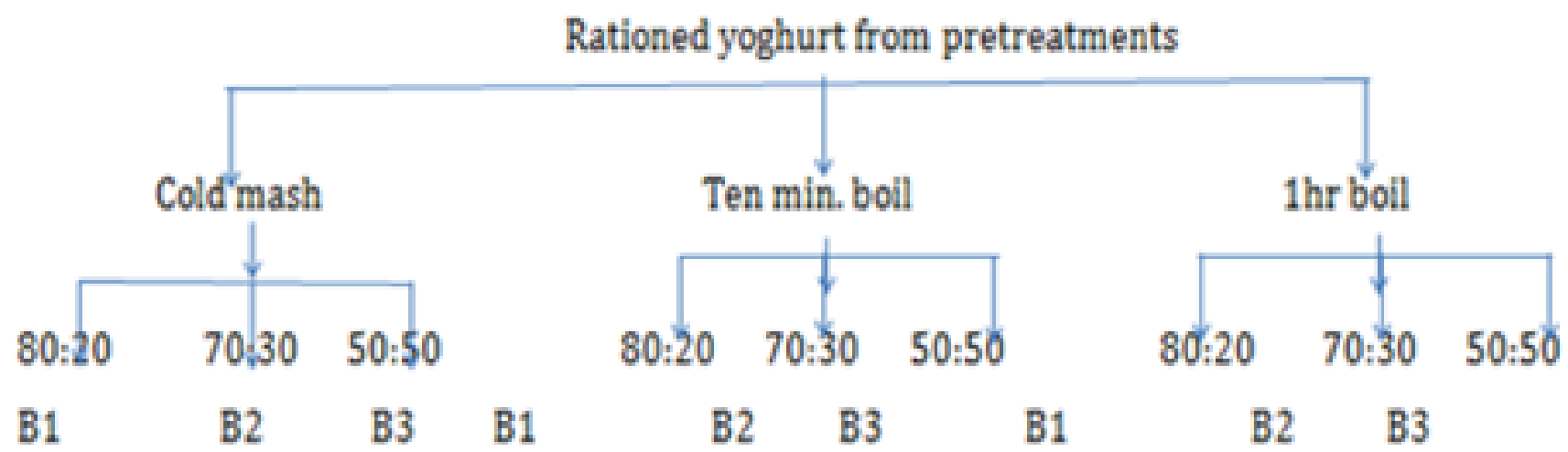

Figure 2 Ration yoghurt from Pre treatments.

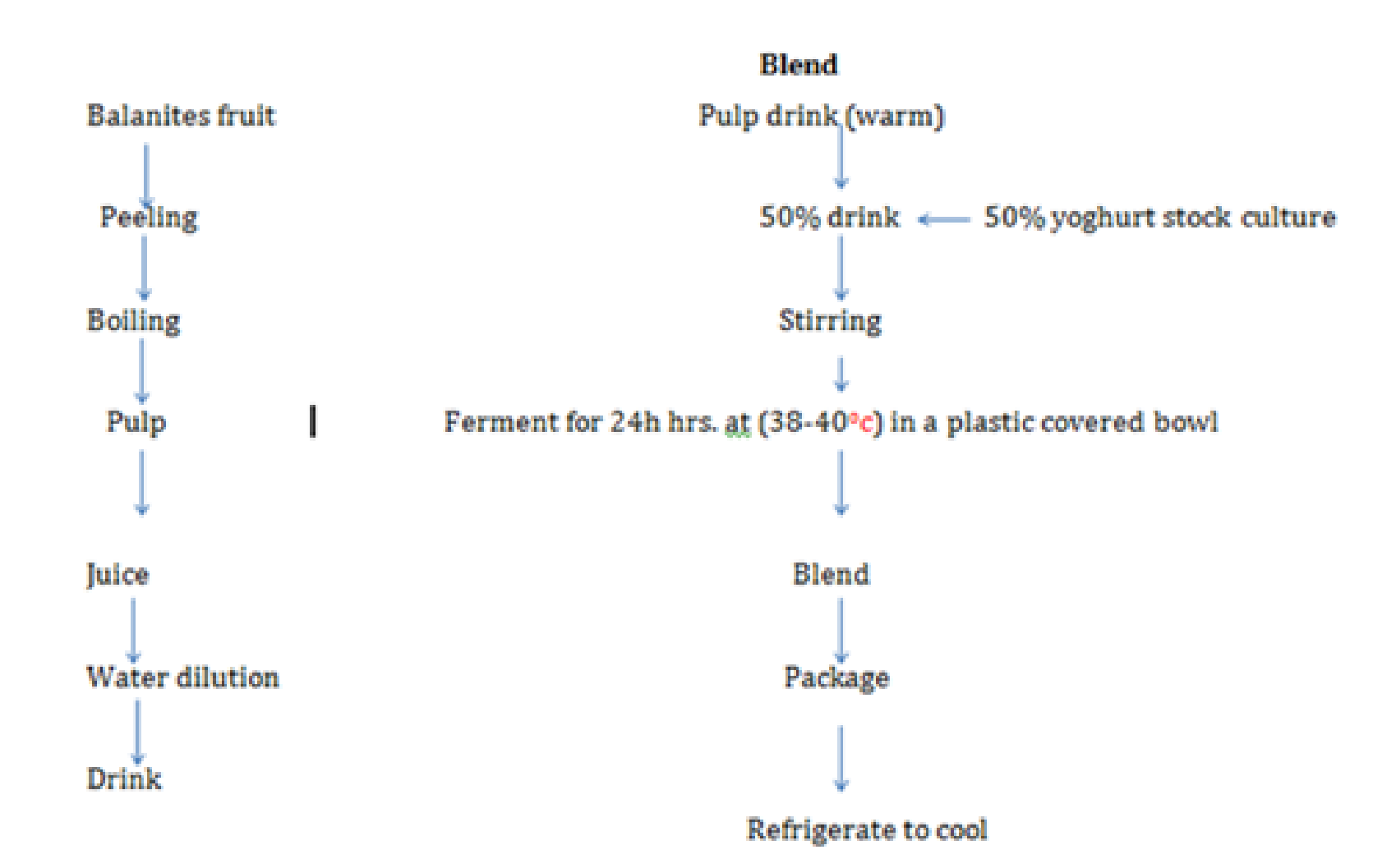

Figure 3 Flow diagram for making balanites pulp drink and (50\%:50\%) yoghurt analogue.

\section{Saponins}

To $0.5 \mathrm{~g}$ of pulp drink and analogue yoghurt were added $5 \mathrm{~mL}$ of distilled water in a test tube. The solutions was shaken vigorously and observed for a stable persistent froth. The frothing was mixed with 3 drops of olive oil and is shaken vigorously. An appearance of creamy mass of small bubbles indicates the presence of saponins.

\section{Tannins}

$0.5 \mathrm{~g}$ of the samples (pulp drink and pulp yoghurt) were boiled for 5 minutes separately in $10 \mathrm{~mL}$ of water in a test tube and then filtered. Drops of $0.1 \%$ ferric chloride was added and was observed. Coloration indicted the presence of tannins.

\section{Flavonoids}

On the sample of pulp drink and yoghurt, fragments of magnesium ribbon were added to the test the drink and yoghurt solution followed by adding Hydrochloric acid, pink scarlet, crimson red or occasionally green to blue colour appears after few minutes.

\section{Analysis of minerals}

The mineral elements of $\mathrm{Zn}, \mathrm{Cu}, \mathrm{mg}, \mathrm{Fe}$ and $\mathrm{Ca}$ were determined.

\section{Flame photometer test}

About $2 \mathrm{~g}$ of liquid drink and control sample were weighed and placed in acid-washed test digestion tubes respectively. TenmL of 
concentrated nitric acid (AnalaR grade, BDH 69\%) was added to the digestion tube. ${ }^{12}$ They were placed in a hot-block digester first at low temperature $\left(40^{\circ} \mathrm{C}\right)$ for 1 hour and then were fully digested at high temperature $\left(130^{\circ} \mathrm{C}\right)$ for 2 hours. The digested samples were then diluted to $40 \mathrm{~mL}$ with double distilled water. After filtration, the metals were determined by using an air-acetylene flame photometer (fp). The data were presented inmg/l. Standard solutions for $\mathrm{Cu}, \mathrm{Fe}$ and $\mathrm{Zn}$ were prepared from $1000 \mathrm{mg} / \mathrm{L}$ stock solutions (MERCK Titrisol). To avoid possible contamination, all glassware and equipment used were washed with acid and the accuracy of the analyses was checked against the blank. Quality control samples made from the standard solutions for $\mathrm{Cu}, \mathrm{Fe}$ and $\mathrm{Zn}$ were analyzed in every 2 samples to check for sample accuracy.

\section{Calcium and magnesium determinations by automated method}

Using Lanthanum interference suppressant solution: About $200 \mathrm{~mL}$. of hydrochloric acid (concentrated, AR grade) were slowly and carefully (fume cupboard) added to $68 \mathrm{~g}$ lanthanum oxide (AR grade) in a 2 I pyrex beaker. Stir the mixture until the lanthanum oxide is completely dissolved, cool, and add it to 200mil deionized distilled water. Dilute to 1 liter with deionized distilled water. This solution contains $58,6 \mathrm{~g} / \mathrm{i}$. La, equivalent to $5 \mathrm{~g} / \mathrm{i}$ in the aspirate. Standard solutions were prepared no addition of caesium-lanthanum solution here. $2 \mathrm{~g}$ Manifold dilution of sodium and magnesium was set and fill into plates. The standard solutions was aspirated and samples, under the conditions stimulated. ${ }^{13}$ The automation operated and record from absorbance values obtained as peaks on a chart recorder. The concentration of each metal ion calculated by reference to the calibration curves obtained by plotting concentrations of the standard solutions versus the corresponding peak heights.

\section{Discussion}

Table 1 shows phytochemical Characteristics of Balanites aeqyptiaca Pulp drink revealed the presence of taninin, saponin, flavonoids and alkaloid bio actives. These bioactive were present in all the pulp drink treated samples, however not strongly present. Alkaloid and flavonoids had been associated with anti-microbial and anti-oxidants function in human system. ${ }^{1,6}$ Tannin and flavonoids may still posse nutritional hindrances in balanites pulp drink. Their presences may have being resuscitated by water dilution on drink making process which might have allowed infinite dilution of the bio ionic material of the phytochemicals especially on the one the hour sample pulp drink treatment.

Table I Phytochemical characteristics of Balanites aeqyptiaca pulp drink

\begin{tabular}{lllll} 
Sample & Tannin & Saponin & Flavonoid & Alkaloid \\
\hline Control & + & + & + & + \\
$\mathrm{Al}$ & + & + & + & + \\
$\mathrm{A} 2$ & + & + & + & + \\
$\mathrm{A} 3$ & + & + & + & +
\end{tabular}

$\mathrm{AI}=10$ minutes heating

$A 2=$ boiled for thour

$\mathrm{A} 3=$ cold juice

Table 2 shows Phytochemical Characteristics of Balanites Aeqyptiaca Pulp yoghurt revealed the presence of some bio-active. Tannin, saponin were absent in the entire sample treated. Flavonoids and alkaloids were observed to be present in all the samples. The masking of these anti-nutritional substances may have come from ration dilution of 50:50 yoghurt stocks to drink solution. ${ }^{14}$ The period for fermentation and the microbial culture successions may have allowed the reuse of the tannin and saponin bioactives. Fermentation generates bio ionic material since redox function comes to play during fermentations. This may have allowed the buildup of this antimicrobial and anti -oxidant flavonoid and alkaloid bio-actives. ${ }^{6}$

Table 2 Phytochemical characteristics of Balanites Aeqyptiaca pulp yoghurt$$
\text { Sample Tannin Saponin Flavonoid Alkaloid }
$$

Control - $\quad$ - $\quad+\quad+$

Al

$\mathrm{A} 2$

A3

Key, $\mathrm{AI}=50.50$ zero cold temperature yoghurt

$A 2=50.50$ one hour boiled yoghurt

$A 3=50.50$ boiled pulp for 10 minutes

Table 3 shows Mineral Analysis of Balanites aeqyptiaca Pulp drink Product at 50:50 pulp juice and water dilution showed that $\mathrm{Zn}$ at $(0.0306 \mathrm{mg} / \mathrm{L}), \mathrm{Cu}(0.6328 \mathrm{mg} / \mathrm{L}), \mathrm{Fe}(2.796 \mathrm{mg} / \mathrm{L}), \mathrm{mg}(18.5767 \mathrm{mg} / \mathrm{L})$ and $\mathrm{Ca}(6.6783 \mathrm{mg} / \mathrm{L})$ were present. Zinc mineral ions, cupper, iron and magnesium in pulp rink were higher than the control sample this revealed that minerals element was made available at these treatment and dilutions. These could be inferred that balanites pulp drink can compete with black currant drink esteemed nutritionally important to fight age and cancer related illnesses. The low presence of $\mathrm{Ca}+$ might have come from inhibitory action of saponin which is confirmed present in the pulp drink (Table 3 ). ${ }^{1}$

Table 4 shows mineral Analysis of Balanites aeqyptiaca Pulp Yoghurt Product showed that $(\mathrm{Zn} 0.6020 \mathrm{mg} / \mathrm{L}),(\mathrm{Cu} 0.326 \mathrm{mg} / \mathrm{L})$, $(\mathrm{Fe} 2.252 \mathrm{mg} / \mathrm{L}),(\mathrm{Mg}, 14.73 \mathrm{mg} / \mathrm{L})$ and $(\mathrm{Ca}, 6.6783 \mathrm{mg})$ were present. Zinc mineral ions and cupper were high in the analogue yoghurt samples compare to control. However Iron, magnesium, and calcium were lower comparing to control. This high content of $\mathrm{Zn}^{+}$and $\mathrm{Cu}^{+}$observations and low $\mathrm{F}^{+}, \mathrm{mg}^{+}$and $\mathrm{Ca}^{+}$in the yoghurt samples may have come from fermentation process that allows the use and generation of certain mineral ions (Appendixes). 
Table 3 Some mineral analysis of Balanites aeqyptiaca pulp drink product

\begin{tabular}{|c|c|c|c|c|c|}
\hline Sample & $\mathrm{Zn}(\mathrm{mg} / \mathrm{L})$ & $\mathrm{Cu}(\mathrm{mg} / \mathrm{L})$ & $\mathrm{Fe}(\mathrm{mg} / \mathrm{L})$ & Mg(mg/L) & $\mathrm{Ca}(\mathrm{mg} / \mathrm{L})$ \\
\hline Control(Black Currant Drink) & 0.025 & 0.0103 & $\mathrm{I} .300 \mathrm{I}$ & 17.1005 & 46.3778 \\
\hline Al & 0.0206 & 0.6328 & 2.796 & 18.5767 & 6.6783 \\
\hline
\end{tabular}

Key, A=Drink from Ihour boiling

Table 4 Some mineral analysis of Balanites aeqyptiaca pulp yoghurt product

\begin{tabular}{|c|c|c|c|c|c|}
\hline Sample & $\mathrm{Zn}(\mathrm{mg} / \mathrm{L})$ & $\mathrm{Cu}(\mathrm{mg} / \mathrm{L})$ & $\mathrm{Fe}(\mathrm{mg} / \mathrm{L})$ & $M g(m g / L)$ & $\mathrm{Ca}(\mathrm{mg} / \mathrm{L})$ \\
\hline
\end{tabular}

Key, $B_{1}=50.50$ blend ration yoghurt

\section{Conclusion}

Phytochemicals were present in the pulp drink and analogue yoghurt, which may have effect on nutrient absorption or metabolism. The mineral contents were abundant especially zinc. Zinc is one critical mineral element for healthy living therefore analogue yoghurt and pulp drink from balanites fruits are good sources. Because of the presences of certain pro-bio actives the yoghurt products will be an excellent anti-oxidant, anti-microbial and mineral substances as well as reduce the burden on dry milk stock which is very expensive in Nigeria. The products are easy to make and abundant hence can alleviate hidden hunger in our rural society as well help against protein energy malnutrition.

\section{Acknowledgements}

The authors acknowledged the grant received from The Tertiary Education Trust Fund (TetFund) through the Federal University, Gashua, Nigeria which made it possible to carry out this work.

\section{Conflict of interest}

Author declares that there is no conflict of interest.

\section{References}

1. Okia CA, Agea JG, Kwetegyeka J, et al. Nutritional Value of Commonly Consumed Desert Date Tree Products. African Crop Science Journal. 2013;21(3):657-667.

2. Siboukeur O. Qualité nutritionnelle, hygiénique etorganoleptique du jus de dattes. USA: Thèse Magister, INA. El-Harrach, Alger; 1997. 106p.

3. Greiner D. The market of date, product of revenue of the oases: in plays, diversity, and tension. Dryness. 1998;9(23):155-162.
4. El Nakhal H, El Sharawy MI, Messalem AS, Tamarheep a new product from dates (Tamar) with high protein content. Food and Agriculture Organization of the UN. 1987;5(1):92-106.

5. Benamara S, Chibane H, Boukhlifa M. Essai deformulation d'un yaourt naturel aux dattes. IAA Actualités techniques et scientifiques, $\mathrm{N}^{\circ} 1 / 2$ mensuel, 2004:11-14.

6. Hayat AC, Salem B. Total Contents of major minerals in the nature yoghurt and in the yoghurts with the date powder of three dry varieties. American journal of food and nutrition. 2011;1(2):74-78.

7. Fiszman SM, Lluch MA, Salvador A. Effect of addition of gelatin on microstructure of acidic milkgels and yoghurt and on their rheological properties. International Dairy Journal. 1999;9:895-901.

8. Tamime AY, Robinson RK, Tamime AY, et al. Yoghurt: Science and technology. 3rd ed. France: Pergamon Press; 1985:7-90.

9. Mikki MS, Al Taisan SM, Abdulaziz AA. Incorporation of date pulp for the manufacture of tomato ketshup. The Food and Agriculture Organization of the UN. 1987;5(2):215-216.

10. Harborne AJ. Phytochemical methods a guide to modern techniques of plant analysis. USA: Springer Science and Business Media; 1998.

11. Trease GE, Evans WC. Pharmacognosy. 12th ed. London: Baillere Tindall; 1983. p. 475-476

12. Official Method of Analysis of AOAC International. 17th ed. USA.

13. Samia FE, Safy ELH, Rabab R, et al. Chemical and nutritional evaluation of different seed flour as novel sources of protein, World Journal of Dairy and food sciences. 2012;7(1):59-65.

14. Sofowara A. Medicinal plants and tropical medicine in Africa. 1993. 